\title{
Cr(III)-Tetraaza Macrocyclic Complexes Containing Auxiliary Ligands (Part II); Synthesis and Characterization of Cr(III)-Citrato Macrocyclic Complex
}

\author{
Jong Chul Byun, 'Yu Chul Park, Jeung Su Youn,, Chung Hun Han, and Nam Ho Lee \\ Department of Chemistry, Research Institute for Basic Sciences, Cheju National University, Jeju 690-756, Korea \\ *E-mail: jchbyun@cheju.ac.kr \\ ${ }^{\dagger}$ Department of Chemistry, Kyungpook National University, Daegu 702-701, Korea \\ ${ }^{\sharp}$ College of Ocean Sciences, Cheju National University, Jeju 690-756, Korea \\ Received November 21, 2004
}

\begin{abstract}
The reaction of cis- $\left[\mathrm{Cr}([14] \text {-decane })\left(\mathrm{OH}_{2}\right)_{2}\right]^{+}([14]$-decane $=$ rac-5,5,7,12,12,14-hexamethyl-1,4,8,11-teraazacyclotetradecane) with auxiliary ligands $\left\{\mathrm{L}_{\mathrm{a}}=\right.$ citrate(cit) $\}$ leads to a new dimeric complex cis- $[\{\mathrm{Cr}([14]-$ decane $\left.)(\mu \text {-cit }\}_{2}\right]\left(\mathrm{ClO}_{4}\right)_{2}$. This binuclear complex has been structurally characterized by a combination of elemental analysis, conductivity, IR and Vis spectroscopy, mass spectrometry, and X-ray crystallography. Analysis of the crystal structure of $c i s-\left[\{\mathrm{Cr}([14] \text {-decane })(\mu \text {-cit })\}_{2}\right]^{+}$reveals that each chromium has a distorted octahedral coordination environment and citrato ligands are monodentate to the two chromium atoms via the carboxyl groups. For dimeric complex the bridging geometry is as follows: $\mathrm{Cr} \cdots \mathrm{Cr}=7.361 \AA$; $\mathrm{Cr}-\mathrm{O}$ (average)

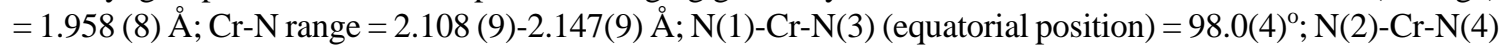
$($ axial position $)=166.4(4)^{\circ} ; \mathrm{O}(1)-\mathrm{Cr}-\mathrm{N}(2)=98.1(4)^{\circ} ; \mathrm{O}(3)-\mathrm{Cr}-\mathrm{N}(4)=96.6(3)^{\circ} ; \mathrm{O}(1)-\mathrm{Cr}-\mathrm{O}(3)=90.4^{\circ}$. The FAB mass spectrum of the dimeric complex displays peak due to the molecular ions $c i s-[\{\mathrm{Cr}([14]-$ decane $)$ $(\mu$-cit $\left.)\}_{2}\right]^{+}$at $m / z 1053$.
\end{abstract}

Key Words : Macrocyclic Cr(III) complex, Bridging citrate ligand, Cr(III) dinuclear complex, Supramolecular species

\section{Introduction}

The nutritional role of chromium(III) has been established of mammals for the maintenance of normal glucose, lipid and protein metabolism. ${ }^{1,2}$ The carcinogenicity of chromium (VI) is considered in terms of the uptake/reduction model. ${ }^{3,4}$ Analysis of chromium containing brewers yeast fractions implied that various amino acids and nicotinic acid served as structural components of the active complexes. ${ }^{5}$ Also, the naturally occurring ligands and their coordination compounds seem to be implied in the therapeutic activity displayed by drugs containing transition metal ions or the ligand itself. ${ }^{6} \mathrm{Cr}(\mathrm{III})$ or $\mathrm{Cr}(\mathrm{VI})$ reacts with many naturally occurring ligands forming several isomeric complexes due to the high affinity of $\mathrm{Cr}$ (III) for $\mathrm{N}, \mathrm{O}$ and/or $\mathrm{S}$ donor atoms. $^{7,8}$ Therefore, the chemistry of chromium with such ligands is obviously of great importance..$^{9,10}$ Despite these results very little is known about the composition and structure of the biologically active forms of chromium.

Due to the presence of carboxyl and hydroxyl functionalities, citric acid \{cit; $\mathrm{HOOCCH}_{2} \mathrm{C}(\mathrm{OH})(\mathrm{COOH}) \mathrm{CH}_{2}-$ $\mathrm{COOH}\}$ is an important compound in biological processes. ${ }^{11}$ A prominent function of the citrate ion is directly related to its metal-chelating capacity, which is manifested in its multi model coordination to various transition metal ions of biological significance. ${ }^{12}$ Such metal ions have been identified as a key metal ion involved in the active sites of essential metalloenzymes related to physiological protective metabolic functions. ${ }^{13}$ Thus, its biological role has been greatly enhanced by its direct involvement as an essential trace element ${ }^{14}$ in functionally critical enzymes such as catalases $^{15}$ and the mitochondrial enzymes superoxide dismutase and pyruvate carboxylase as well as the glialspecific enzyme glutamine synthetase. ${ }^{16}$ In this context, studies about the coordination chemistry of citrate ligand have been dealed with several metals. ${ }^{17}$ However, little work has been carried out on the preparations of macrocyclic chromium(III) complexes with naturally occurring citrate ligands. ${ }^{18}$

We describe herein the preparation, isolation, and spectroscopic and structural characteriztions of the first dimeric chromium(III) macrocyclic complex \{cis-[\{Cr(III)([14]decane $\left.\left.)\left(\mathrm{L}_{\mathrm{a}}\right)\right\}_{2}\right]^{2+}, \quad[14]$-decane; rac- $(5,5,7,12,12,14$-hexamethyl-1,4,8,11-tetraazacyclotetradecane) $\}$ containing auxiliary ligand $\left(\mathrm{L}_{\mathrm{a}}\right)$, citrate ligand in its coordination sphere (Scheme 1). The interactions between $\mathrm{Cr}$ (III) and these ligands are of great importance in view of the presumed role of the $\mathrm{Cr}-\mathrm{N}$, $\mathrm{O}$ bond in the biochemical processes. These compounds are also interesting for their role as unique models in studying complex formation with various substrates.

\section{Experimental Section}

Measurements. All chemicals were commercial analytical reagents and were used without further purification. For the spectroscopic and physical measurements, organic solvents were dried and purified according to the literature methods. ${ }^{19}$ Nanopure quality water was used throughout this work. Macrocyclic rac-[14]-decane ligand, cis-[Cr([14]- 


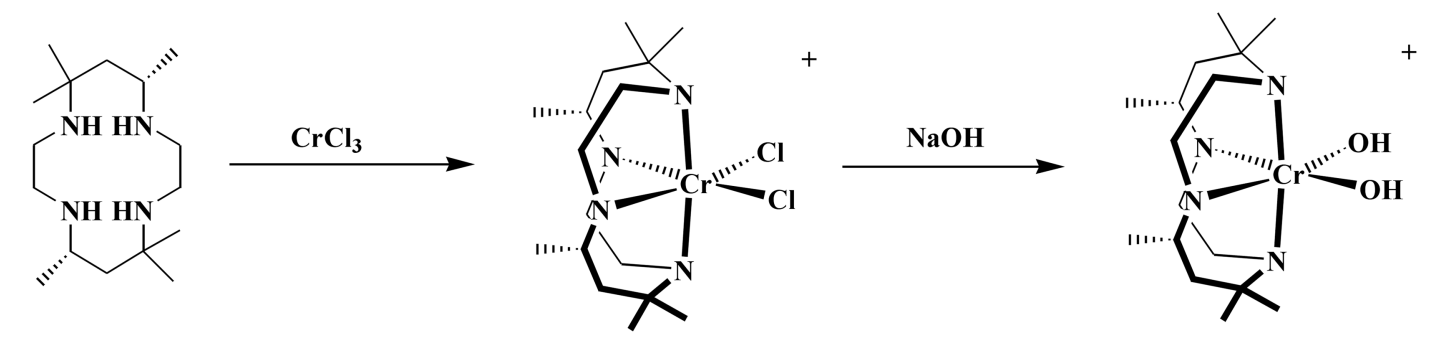

rac-[14]-decane

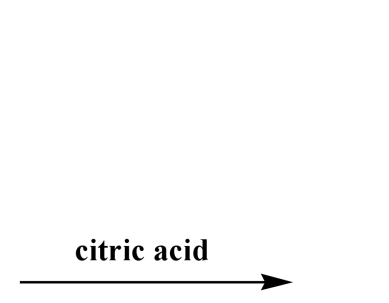

cis- $\left[\mathrm{Cr}([14]-\text { decane })(\mathrm{CI})_{2}\right]^{+}$
cis-[Cr([14]-decane $\left.)(\mathrm{OH})_{2}\right]^{+}$

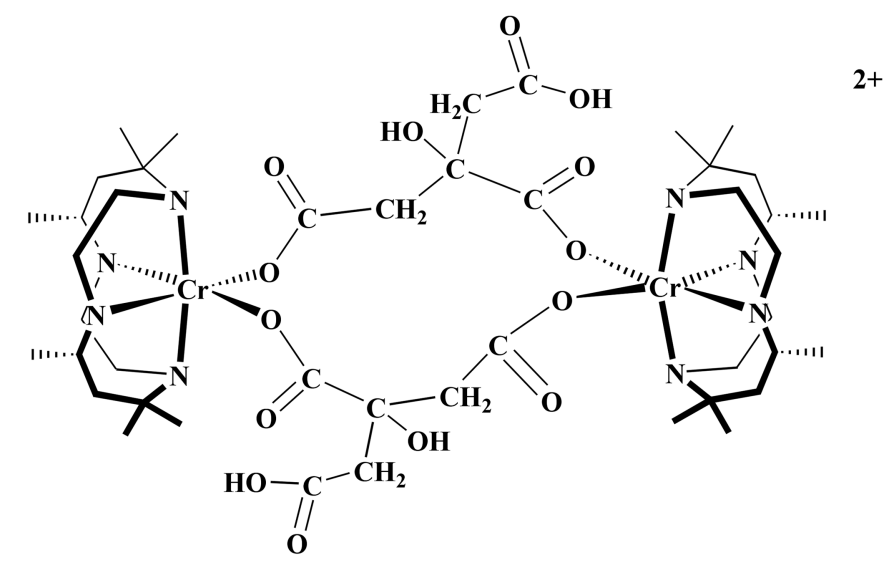

$\operatorname{cis-}\left[\{\operatorname{Cr}([14]-d e c a n e)(\mu-c i t)\}_{2}\right]^{2+}$

Scheme 1. Synthetic route of the $\operatorname{cis}-\left[\{\operatorname{Cr}([14] \text {-decane })(\mu \text {-cit })\}_{2}\right]^{2+}$.

decane $\left.) \mathrm{Cl}_{2}\right] \mathrm{Cl}$ and cis-[Cr([14]-decane $\left.)(\mathrm{OH})_{2}\right]^{+}$solution were prepared according to the literature methods previously reported. ${ }^{20-22}$ Microanalyses of $\mathrm{C}, \mathrm{H}$, and $\mathrm{N}$ was carried out using LECO CHN-900 analyzer. Conductance measurement of the complex was performed in DMF at $25 \pm 1{ }^{\circ} \mathrm{C}$ using an ORION 162 conductivity temperature meter. IR spectrum was recorded with a Bruker FSS66 FT-IR spectrometer. Electronic absorption spectrum was measured at $25{ }^{\circ} \mathrm{C}$ on a HP model 8453 UV-VIS Spectrophotometer. FAB-mass spectrum was obtained on a JEOL JMS-700 Mass Spectrometer using argon $(6 \mathrm{kV}, 10 \mathrm{~mA})$ as the FAB gas. The accelerating voltage was $10 \mathrm{kV}$ and glycerol was used as the matrix. The mass spectrometer was operated in positive ion mode and mass spectrum was calibrated by Alkali-CsI positive.

Preparation of cis-[\{Cr([14]-decane $)(\mu$-cit $\left.)\}_{2}\right]\left(\mathrm{ClO}_{4}\right)_{2}$ -6H $\mathbf{H}_{2} \mathbf{O}$. To a freshly prepared $4 \times 10^{-3} \mathrm{M}$ cis-[Cr([14]decane $\left.)(\mathrm{OH})_{2}\right]^{+}$solution $(10 \mathrm{~mL})$, a solution of citric acid $(2$ $\mathrm{g})$ in $\mathrm{H}_{2} \mathrm{O}(20 \mathrm{~mL})$ was slowly added in small portions. To this was added dropwise a saturated aqueous $\mathrm{NaClO}_{4}$ solution $(4 \mathrm{~mL})$ with stirring and solution was refluxed for 5 min. The resulting solution was allowed to stand in a refrigerator $\left(\sim 2{ }^{\circ} \mathrm{C}\right)$ until precipitates formed. The precipitates were filter, washed twice with ice-cold water, and dried in vacuo. Yield 34\%. Anal. Calc. for $\mathrm{C}_{44} \mathrm{H}_{84} \mathrm{~N}_{8} \mathrm{O}_{22} \mathrm{Cl}_{2} \mathrm{Cr}_{2}$ . $6 \mathrm{H}_{2} \mathrm{O}$ : C, 38.85; H, 7.11; N, 8.24. Found: C, 38.88; H, 6.97; $\mathrm{N}, 8.21 . \lambda_{\mathrm{M}}(\mathrm{DMF}): 168.6 \mathrm{ohm}^{-1} \mathrm{~cm}^{2} \mathrm{~mol}^{-1}$.

Determination of crystal structure. Crystals of cis$\left[\{\mathrm{Cr}([14] \text {-decane })(\mu \text {-cit })\}_{2}\right]\left(\mathrm{ClO}_{4}\right)_{2} \cdot 8 \mathrm{H}_{2} \mathrm{O}$ suitable for $\mathrm{X}$-ray diffraction study were obtained by slow evaporation of acetonitrile : $\mathrm{H}_{2} \mathrm{O}(1: 1)$ solutions of the complex. A pink crystal of complex was mounted on a glass fiber and coated with epoxy resin. The single crystal data for the complex were collected on an Kappa CCD diffractometer equipped with graphite-monochromated Mo $\mathrm{K} \alpha$ radiation $(\lambda=$ $0.71073 \AA$ ). The crystallographic data, conditions for the collection of intensity data, and some features of the structure refinements are listed in Table 1 . The intensity data were corrected for Lorentz and polarization effects. Absorption correction was not made during processing. Of the 2968 unique reflections measured, 2897 reflections in the range $1.44^{\circ} \leq 2 \theta \leq 19.76^{\circ}$ were considered to be observed $(I>2 \sigma(I))$ and were used in subsequent structure analysis. The structure was solved by the direct method, ${ }^{23}$ and refined by full-matrix least-squares refinement with use of the SHELXL-97 package program. ${ }^{24}$ The centrosymmetric space group was chosen, and this choice was confirmed by the successful determination of the chromium atom position from the Patterson map and finally a structure solution with acceptable thermal parameters and geometry for octahedral $\mathrm{Cr}(\mathrm{III})$. All atoms of the dimeric complex were refined anisotropically, but the water hydrogens were refined isotropically. The water hydrogens were difficult to find in the difference maps, but surprisingly easy to refine to very reasonable positions (Table 4). Selected bond lengths and bond angles are presented in Table 2 and 3, and the hydrogen-bond lengths and angles are given in Table 4.

Crystallographic data for the structure reported here have 
Table 1. Crystallographic data for cis- $\left[\{\mathrm{Cr}([14]-\text { decane })(\mu \text {-cit })\}_{2}\right]$ $\left(\mathrm{ClO}_{4}\right)_{2} \cdot 8 \mathrm{H}_{2} \mathrm{O}$

\begin{tabular}{|c|c|}
\hline Formula & $\mathrm{C}_{22} \mathrm{H}_{50} \mathrm{ClCrN}_{4} \mathrm{O}_{15}$ \\
\hline Formula weight & 698.11 \\
\hline Radiation $(\AA)$ & Mo K $\alpha(0.71073)$ \\
\hline Crystal system & monoclinic \\
\hline Space group & $\mathrm{C} 2 / \mathrm{c}$ \\
\hline$a(\AA)$ & $23.818(2)$ \\
\hline$b(\AA)$ & $21.139(2)$ \\
\hline$c(\AA)$ & $16.1350(10)$ \\
\hline$\alpha\left({ }^{\circ}\right)$ & 90 \\
\hline$\beta\left({ }^{\circ}\right)$ & $127.294(4)$ \\
\hline$\gamma\left({ }^{\circ}\right)$ & 90 \\
\hline$V\left(\AA^{3}\right)$ & $6462.8(9)$ \\
\hline$Z$ & 8 \\
\hline$T(\mathrm{~K})$ & 293(2) \\
\hline$D_{\text {calc }}\left(\mathrm{gcm}^{-3}\right)$ & 1.435 \\
\hline$\theta$ Range of data collected & $1.44-19.76$ \\
\hline$F_{000}$ & 2968 \\
\hline$\mu\left(\mathrm{mm}^{-1}\right)$ & 0.509 \\
\hline no. of obsd data $(\mathrm{I}>2 \sigma(\mathrm{I}))$ & 2897 \\
\hline no. variable & 387 \\
\hline Goodness of fit & 1.099 \\
\hline$R$ & 0.0865 \\
\hline$R_{\mathrm{w}}$ & 0.2574 \\
\hline
\end{tabular}

been deposited with Cambridge Crystallographic Data Centre (Deposition No. CCDC-247580). The data can be obtained free of charge via www.ccdc.cam.ac.uk/conts/ retrieving.html (or from the CCDC, 12 Union Road, Cambridge CB2 1EZ, UK; fax: +44 1223 336033; e-mail: deposit@ccdc.cam.ac.uk).

\section{Results and Discussion}

Properties of cis-[Cr([14]-decane $\left.)(\mathrm{OH})_{2}\right]^{+}$solution. The cation of cis- $\left[\mathrm{Cr}([14]\right.$-decane $\left.)(\mathrm{OH})_{2}\right] \mathrm{ClO}_{4} \cdot 3 \mathrm{H}_{2} \mathrm{O}$ behaves as a divalent base in aqueous solution. ${ }^{21} \mathrm{~A}$ DMF solution of this complex displayed a molar conductance of 71.4 $\mathrm{ohm}^{-1} \mathrm{~cm}^{2} \mathrm{~mol}^{-1}$, which is in the range of $1: 1$ electrolyte. From the acid dissociation constants ${ }^{21}$ it is seen that the cis$\left[\mathrm{Cr}([14] \text {-decane })\left(\mathrm{OH}_{2}\right)_{2}\right]^{3+}$ cation is a significantly stronger acid than a number of other cis-tetraaminediaquachromium (III) cations. This result is due to differences in cationsolvent interactions by the restriction of ligand cyclization, steric effects, and hydrophobic bonding effect.

It shows that the absorption bands shift to shorter wavelength on addition of $\mathrm{HClO}_{4}$ solution to the aqueous $\mathrm{Cr}$ (III) complex solution. The absorption spectrum of this species is compared with several related compounds in Table 5. The first LF band $\left({ }^{4} \mathrm{~A}_{2 \mathrm{~g}} \rightarrow{ }^{4} \mathrm{~T}_{2 \mathrm{~g}} ; O_{h}\right.$ symmetry) is observed at $612 \mathrm{~nm}$, while the second LF band $\left({ }^{4} \mathrm{~A}_{2 \mathrm{~g}} \rightarrow{ }^{4} \mathrm{~T}_{1 \mathrm{~g}}\right)$ is centered at $379 \mathrm{~nm} .{ }^{8,25}$ The molar absorptivities of the two $d-d$ bands are substantially greater than those of the trans analogues, consistent with the given geometric assignment. However, the first $d-d$ band for $c i s-\left[\mathrm{Cr}(\operatorname{cyclam})\left(\mathrm{NH}_{3}\right)_{2}\right]^{3+}$, cis- $\left[\mathrm{Cr}([14]-\text { decane })(\mathrm{OH})_{2}\right]^{+}$, and cis- $\left[\mathrm{Cr}([14] \text {-decane })\left(\mathrm{H}_{2} \mathrm{O}\right)_{2}\right]^{3+}$ complex ions is characterized by an increased intensity and a lower energy than that for $c i s-\left[\mathrm{Cr}(\mathrm{en})_{2}\left(\mathrm{NH}_{3}\right)_{2}\right]^{3+}$. This result indicates that, for these cis systems, cyclam and [14]-decane are slightly lower in the spectrochemical series than ethylenediamine (en). These effects may qualitatively be accounted for geometric structure of complex which shows a distorted octahedral geometry of the $\mathrm{CrN}_{6}\left(\mathrm{~L}_{\mathrm{a}}=\mathrm{NH}_{3}\right)$ or $\mathrm{CrN}_{4} \mathrm{O}_{2}\left(\mathrm{~L}_{\mathrm{a}}=\mathrm{H}_{2} \mathrm{O}\right.$ and $\left.\mathrm{OH}^{-}\right)$apparently induced by two methyl groups above and below the $\mathrm{CrN}_{4}$ (secondary amine nitrogen atoms of the macrocycle) plane.

Description of crystal structure. Only a few chromium (III)-tetraazacyclotetradecane complexes have been reported in the literature. ${ }^{26}$ To our knowledge, this is the first reported structure of a cis-[\{Cr([14]-decane $)(\mu$-cit $\left.)\}_{2}\right]\left(\mathrm{ClO}_{4}\right)_{2} \cdot 8 \mathrm{H}_{2} \mathrm{O}$ complex containing naturally occurring auxiliary ligands. The structure and labeling scheme for dinuclear cation cis$\left[\{\mathrm{Cr}([14] \text {-decane })(\mu \text {-cit })\}_{2}\right]^{2+}$ is depicted in Figure 1. The crystal structure of this complex is composed of dimeric cation of the indicated formula and noninteracting perchlorate anions. These results are backed up by the elemental analysis and molar conductivity $\left(\lambda_{\mathrm{M}}=168.6\right.$ $\mathrm{ohm}^{-1} \mathrm{~cm}^{2} \mathrm{~mol}^{-1}$ ) which agreed with assignment of the structure as cis- $\left[\{\mathrm{Cr}([14] \text {-decane })(\mu \text {-cit })\}_{2}\right]\left(\mathrm{ClO}_{4}\right)_{2} \cdot 8 \mathrm{H}_{2} \mathrm{O}$.

The geometry consists of two roughly octahedrally coordinated chromium atoms, each with four secondary amine nitrogen atoms of the macrocycle and two oxygen atoms of the bridging citrato ligands. Two citrate ions in this complex coordinate to two chromium(III) ions in an unusual monodentate mode. Namely, each citrate ion coordinate with two chromium(III) ions via its $\alpha$-carboxyl and one of the $\beta$ carboxyl groups, while the other $\beta$-carboxyl group does not participate in the coordination. The uncoordinated oxygen atom $\{\mathrm{O}(2)$ and $\mathrm{O}(4)\}$ of the carboxylate groups and the secondary amines of the macrocycle involve in the formation of stable six-membered hydrogen bonded rings. The macrocycles in this complex are flexible and foldable when the bridging citrate anions bind to the chromium(III) ions, occupying the citrate anions cis-positions in the coordination sphere of the chromium(III) ions, and
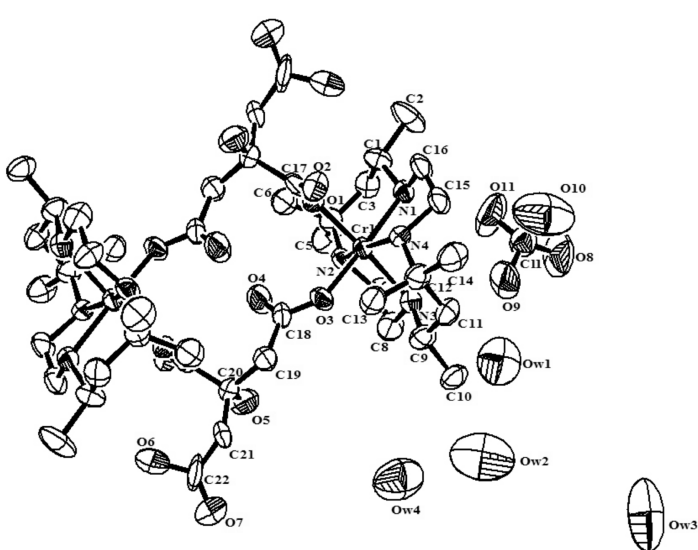

Figure 1. ORTEP plot of the cis-[\{Cr([14]-decane $)(\mu$-cit $\left.)\}_{2}\right]-$ $\left(\mathrm{ClO}_{4}\right)_{2} \cdot 8 \mathrm{H}_{2} \mathrm{O}$ complex. 
Table 2. Selected bond lengths (̊̊) for cis-[\{Cr([14]-decane) $(\mu$-cit $\left.)\}_{2}\right]\left(\mathrm{ClO}_{4}\right)_{2} \cdot 8 \mathrm{H}_{2} \mathrm{O}$

\begin{tabular}{llll}
\hline $\mathrm{Cr}(1)-\mathrm{O}(3)$ & $1.942(8)$ & $\mathrm{N}(1)-\mathrm{C}(1)$ & $1.54(2)$ \\
$\mathrm{Cr}(1)-\mathrm{O}(1)$ & $1.974(8)$ & $\mathrm{N}(2)-\mathrm{C}(7)$ & $1.49(2)$ \\
$\mathrm{Cr}(1)-\mathrm{N}(1)$ & $2.108(9)$ & $\mathrm{N}(2)-\mathrm{C}(4)$ & $1.55(2)$ \\
$\mathrm{Cr}(1)-\mathrm{N}(3)$ & $2.111(9)$ & $\mathrm{N}(3)-\mathrm{C}(8)$ & $1.503(14)$ \\
$\mathrm{Cr}(1)-\mathrm{N}(4)$ & $2.117(9)$ & $\mathrm{N}(3)-\mathrm{C}(9)$ & $1.51(2)$ \\
$\mathrm{Cr}(1)-\mathrm{N}(2)$ & $2.147(9)$ & $\mathrm{N}(4)-\mathrm{C}(15)$ & $1.501(14)$ \\
$\mathrm{N}(1)-\mathrm{C}(16)$ & $1.494(14)$ & $\mathrm{N}(4)-\mathrm{C}(12)$ & $1.50(2)$ \\
\hline
\end{tabular}

Table 3. Selected bond angles $\left({ }^{\circ}\right)$ for cis-[\{Cr([14]-decane) $(\mu$-cit $\left.)\}_{2}\right]\left(\mathrm{ClO}_{4}\right)_{2} \cdot 8 \mathrm{H}_{2} \mathrm{O}$

\begin{tabular}{lrlr}
\hline $\mathrm{O}(3)-\mathrm{Cr}(1)-\mathrm{O}(1)$ & $90.4(3)$ & $\mathrm{N}(1)-\mathrm{Cr}(1)-\mathrm{N}(4)$ & $83.7(4)$ \\
$\mathrm{O}(3)-\mathrm{Cr}(1)-\mathrm{N}(1)$ & $177.2(4)$ & $\mathrm{N}(3)-\mathrm{Cr}(1)-\mathrm{N}(4)$ & $86.6(4)$ \\
$\mathrm{O}(1)-\mathrm{Cr}(1)-\mathrm{N}(1)$ & $86.8(3)$ & $\mathrm{O}(3)-\mathrm{Cr}(1)-\mathrm{N}(2)$ & $92.4(3)$ \\
$\mathrm{O}(3)-\mathrm{Cr}(1)-\mathrm{N}(3)$ & $84.8(4)$ & $\mathrm{O}(1)-\mathrm{Cr}(1)-\mathrm{N}(2)$ & $98.1(4)$ \\
$\mathrm{O}(1)-\mathrm{Cr}(1)-\mathrm{N}(3)$ & $174.8(4)$ & $\mathrm{N}(1)-\mathrm{Cr}(1)-\mathrm{N}(2)$ & $87.8(4)$ \\
$\mathrm{N}(1)-\mathrm{Cr}(1)-\mathrm{N}(3)$ & $98.0(4)$ & $\mathrm{N}(3)-\mathrm{Cr}(1)-\mathrm{N}(2)$ & $84.1(4)$ \\
$\mathrm{O}(3)-\mathrm{Cr}(1)-\mathrm{N}(4)$ & $96.6(3)$ & $\mathrm{N}(4)-\mathrm{Cr}(1)-\mathrm{N}(2)$ & $166.4(4)$ \\
$\mathrm{O}(1)-\mathrm{Cr}(1)-\mathrm{N}(4)$ & $92.0(4)$ & $\mathrm{Cr}(1)-\mathrm{O}(1)-\mathrm{C}(17)$ & $134.1(7)$ \\
& & $\mathrm{Cr}(1)-\mathrm{O}(3)-\mathrm{C}(18)$ & $134.3(8)$ \\
\hline
\end{tabular}

producing dimeric structure.

Selected bond distances and angles are listed in Table 2 and 3. The $\mathrm{Cr}-\mathrm{N}$ (secondary amines) bond lengths for dimeric complex range from 2.108(9) to 2.147(9) $\AA$. These data are comparable with those for $[\mathrm{Ni}(\mathrm{L}-1)(\text { oxalato })]_{n}$ - $n \mathrm{H}_{2} \mathrm{O}$ (L-1; tetraaza macrocycles) \{2.0628(18)-2.1088(18) $\AA 3,{ }^{18}$ cis-[Cr([14]-decane $\left.)\left(\mathrm{O}_{2} \mathrm{CO}\right)\right]^{+}(2.091-2.111 \AA),{ }^{26(\mathrm{a})}$ and $\quad c i s-\left[\mathrm{Cr}([14]\right.$-decane $\left.)(\mathrm{CN})_{2}\right] \mathrm{Cl} \quad\{2.119(3)-2.135(2)$ $\AA$ \} ${ }^{26(b)}$ The bond angles of $\mathrm{N}(1)-\mathrm{Cr}-\mathrm{N}(3)$ (equatorial position), $\mathrm{N}(2)-\mathrm{Cr}-\mathrm{N}(4)$ (axial position), $\mathrm{O}(1)-\mathrm{Cr}-\mathrm{N}(2)$ and $\mathrm{O}(3)-\mathrm{Cr}-\mathrm{N}(4)$ are 98.0(4), 166.4(4), 98.1(4) and 96.6(3) ${ }^{\circ}$, respectively. The average $\mathrm{Cr}-\mathrm{O}$ bridging distance of $1.958(8)$ $\AA$ is shorter than the $\mathrm{Cr}-\mathrm{N}$ distances and comparable with the observed for the $\left[\mathrm{VO}_{2}(\mathrm{cit})\right]_{2}{ }^{6-27(\mathrm{a})}\left[\mathrm{VO}_{2}(\mathrm{cit})\right]_{2}{ }^{2-27(\mathrm{~b})}[\mathrm{Cr}(\mathrm{L}-$ 2) $\left.(\mathrm{OH})\left(\mathrm{CH}_{3} \mathrm{COO}\right)_{2}\right]\left(\mathrm{ClO}_{4}\right)_{3} \quad(\mathrm{~L}-2 ;$ macrocyclic tridentate amine $){ }^{27(\mathrm{c})}$ As expected the $\mathrm{Cr}-\mathrm{Cr}(-x+0.5,-y+0.5,-z)$ separation of $7.361 \AA$ is significantly longer than those observed for $[\mathrm{Ni}(\mathrm{L}-1) \text { (oxalato) }]_{n} \bullet n \mathrm{H}_{2} \mathrm{O},{ }^{18}\left[\mathrm{VO}_{2} \text { (cit) }\right]_{2}{ }^{6-2},{ }^{27(\text { a })}$ $\left[\mathrm{VO}_{2}(\mathrm{cit})\right]_{2}{ }^{2-},{ }^{27(\mathrm{~b})}$ and $\left[\mathrm{Cr}(\mathrm{L}-2)(\mathrm{OH})\left(\mathrm{CH}_{3} \mathrm{COO}\right)_{2}\right]\left(\mathrm{ClO}_{4}\right)_{3} .^{27(\mathrm{c})}$ The $\mathrm{Cr}-\mathrm{O}(1)-\mathrm{C}(17)$ and $\mathrm{Cr}-\mathrm{O}(3)-\mathrm{C}(18)$ bridging angles are 134.1(7) and $134.3(8)^{\circ}$, and the $\mathrm{O}(1)-\mathrm{Cr}-\mathrm{O}(3)$ angle is $90.4^{\circ}$. These values are parallel to those found in the dimers of other chromium(III) tetradentate complexes containing bridging ligands. ${ }^{27,28}$

It is of interest to note the axial vs. equatorial coordination of the macrocycle and the citrato groups for each chromium atom. It is known that in cis octahedral complexes of macrocycles of medium size (12-14 membered rings) the pattern of metal-ligand distance and the angle between the axial donors and the metal center are particularly affected by the cavity size. In this complex $\mathrm{Cr}-\mathrm{N}$ (1, equatorial; 2.108(9) $\AA$ ) and $\mathrm{Cr}-\mathrm{N}$ (3, equatorial; 2.111(9) $\AA$ ) distances are shorter

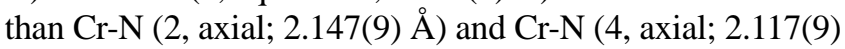
$\AA$ ) and the angle $\mathrm{N}(2)-\mathrm{Cr}-\mathrm{N}(4)\left(166.4(4)^{\circ}\right)$ is smaller than the ideal value of $180^{\circ}$, indicating that the donor atoms are not

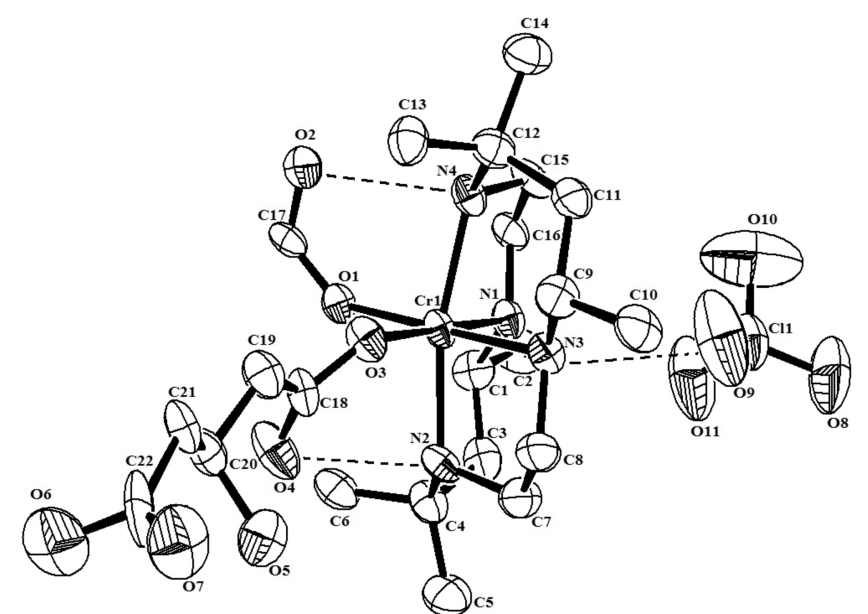

Figure 2. Hydrogen-bonding scheme in the cis-[\{Cr([14]decane $)(\mu$-cit $\left.)\}_{2}\right]\left(\mathrm{ClO}_{4}\right)_{2} \cdot 8 \mathrm{H}_{2} \mathrm{O}$ complex.

able to achieve the axial positions of a perfect octahedron. In cis-[Cr(cyclam $) \mathrm{Cl}(\mathrm{dmso})]^{2+}$ octahedral complex, the angle $\mathrm{N}_{\text {axial }}-\mathrm{Cr}-\mathrm{N}_{\text {axial }}$ is closer to $180^{\circ}$ than the title complex and the axial and equatorial distances take similar values. ${ }^{29,30}$

As is usual in the saturated 14-membered tetraaza macrocyclic complexes, the N-Ni-N angle of the sixmembered chelate rings $\left\{86.6(4), 87.8(4)^{\circ}\right\}$ is larger than that of the five-membered chelate rings $\left(83.7(4), 84.1(4)^{\circ}\right\}$.

In general, hydrogen bonding plays a principal role in the packing of the title compound. There are twelve types of $\mathrm{H}-$ bonds, including $\mathrm{N}(2)-\mathrm{O}(4), \mathrm{O}(4)-\mathrm{O}(5)$, and $\mathrm{O}(2)-\mathrm{Ow}(5)$ (Fig. 3 and Table 4). The uncoordinated oxygen atom of each citrate ligand as well as of counter ion, $\mathrm{ClO}_{4}{ }^{-}$give rise to hydrogen bonds with secondary amine hydrogens of the macrocycle (Fig. 2). These interactions result in a formation of polymeric chains (Fig. 3). This chain forms a related layer structure, but within the layers dinuclear cation cis$\left[\{\mathrm{Cr}([14] \text {-decane })(\mu \text {-cit })\}_{2}\right]^{2+}$ ions arrange zig-zag configurations. The hydrogen bonds between secondary amine hydrogens of the macrocycle and $\mathrm{ClO}_{4}{ }^{-}$ion, $\mathrm{N}(3)-\mathrm{O}(9)$ (Table 4) connect the chains to the layers. Between the layers hydrogen bonding interactions auxiliary ligands and

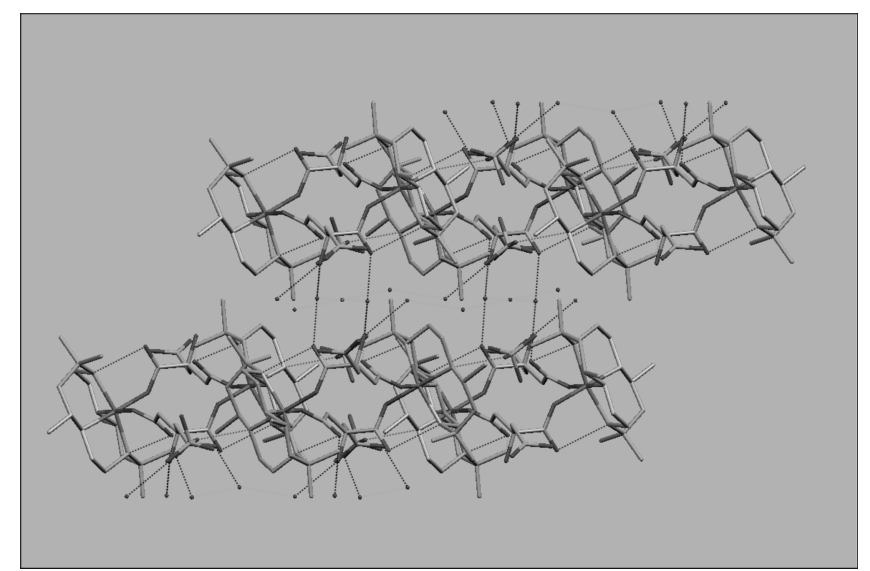

Figure 3. The molecular packing diagram of cis-[\{Cr([14]decane $)(\mu$-cit $\left.)\}_{2}\right]\left(\mathrm{ClO}_{4}\right)_{2} \cdot 8 \mathrm{H}_{2} \mathrm{O}$. 
Table 4. Selected bond lengths $\left({ }^{\circ} \mathrm{p}\right)$ and bond angles $\left(\phi^{\mathrm{TM}}\right)$ for hydrogen bond of $c i s-\left[\{\mathrm{Cr}([14]-\text { decane })(\mu \text {-cit })\}_{2}\right]\left(\mathrm{ClO}_{4}\right)_{2} \cdot 8 \mathrm{H}_{2} \mathrm{O}$

\begin{tabular}{|c|c|c|c|}
\hline \multicolumn{4}{|l|}{ macrocycle-auxiliary ligand (citrate ion) } \\
\hline $\mathrm{N}(2)-\mathrm{O}(4)$ & 2.989 & $\mathrm{~N}(2)-\mathrm{H}(2)-\mathrm{O}(4)$ & 144.42 \\
\hline $\mathrm{N}(4)-\mathrm{O}(2)$ & 2.845 & $\mathrm{~N}(4)-\mathrm{H}(4)-\mathrm{O}(2)$ & 153.92 \\
\hline \multicolumn{4}{|l|}{ auxiliary ligand } \\
\hline $\mathrm{O}(4)-\mathrm{O}(5)$ & 3.003 & $\mathrm{O}(4)-\mathrm{H}(5)-\mathrm{O}(5)$ & 130.22 \\
\hline \multicolumn{4}{|l|}{ macrocycle- $\mathrm{ClO}_{4}^{-}$ion } \\
\hline $\mathrm{N}(3)-\mathrm{O}(9)$ & 2.904 & $\mathrm{~N}(3)-\mathrm{H}(3)-\mathrm{O}(9)$ & 161.09 \\
\hline \multicolumn{4}{|l|}{ auxiliary ligand-water molecule } \\
\hline $\mathrm{O}(2)-\mathrm{Ow}(5)(1 / 2+\mathrm{x}, 1 / 2-\mathrm{y},-1 / 2+\mathrm{z})$ & 2.902 & $\mathrm{O}(5)-\mathrm{Ow}(3)(-\mathrm{x}, \mathrm{y}, 1 / 2+\mathrm{z})$ & 2.761 \\
\hline $\mathrm{O}(6)-\mathrm{Ow}(4)(\mathrm{x}, 1-\mathrm{y},-1 / 2+\mathrm{z})$ & 2.744 & $\mathrm{O}(7)-\mathrm{Ow}(2)(-\mathrm{x}, \mathrm{y}, 1 / 2-\mathrm{z})$ & 2.762 \\
\hline $\mathrm{O}(7)-\mathrm{Ow}(4)(-\mathrm{x}, 1-\mathrm{y},-\mathrm{z})$ & 2.732 & & \\
\hline \multicolumn{4}{|l|}{ water molecules } \\
\hline $\mathrm{Ow}(1)-\mathrm{Ow}(2)$ & 3.004 & $\mathrm{Ow}(2)-\mathrm{Ow}(4)$ & 2.655 \\
\hline $\mathrm{Ow}(4)-\mathrm{Ow}(3)(-\mathrm{x}, \mathrm{y}, 1 / 2-\mathrm{z})$ & 2.731 & & \\
\hline
\end{tabular}

water $\{\mathrm{O}(2)-\mathrm{Ow}(5)(1 / 2+x, 1 / 2-y,-1 / 2+z) ; 2.902 \AA$, $\mathrm{O}(6)-\mathrm{Ow}(4)(x, 1-y,-1 / 2+z) ; 2.744 \AA$, O(7)-Ow(4) $(-x, 1$ $-y,-z) ; 2.732 \AA, \mathrm{O}(5)-\mathrm{Ow}(3)(-x, y, 1 / 2+z) ; 2.761 \AA$, and $\mathrm{O}(7)-\mathrm{Ow}(2)(-x, y, 1 / 2-z) ; 2.762 \AA$ \} are observed.

The distance and arrangement in space of the two metal ions are determined by the structure of the bridges, whereas their properties depend on the nature of the bridging ligands with macrocyles. Therefore, dinuclear complexes such as title compound is a good candidate for a supramolecular species. Indeed, cis- $\left[\{\mathrm{Cr}([14]-\text { decane })(\mu \text {-cit })\}_{2}\right]^{2+}$ as artificial receptor contains intramolecular cavity $\{\mathrm{Cr}-\mathrm{Cr}(-x+$ $0.5,-y+0.5,-z)$ distance; 7.361(3) $\AA$ \} sufficiently large to allow substrate inclusion as well as structural elements that endow the three dimensional framework with planned geometric and dynamic features. ${ }^{31}$ On that account, the title complex may be considered generalized coordination chemistry. It extends the purpose of designed organic complexing agents from the coordination of transition metal ions, for which they were first used, to the coordination of all kinds of substrates: cationic, anionic, and neutral species of an inorganic, organic, or biological nature. Thus, the functional properties of a title compound may cover molecular recognition, catalysis (transformation), and transport (translocation).

Electronic absorption spectrum. The absorption spectrum of the dimer, cis- $\left[\{\mathrm{Cr}([14] \text {-decane })(\mu \text {-cit })\}_{2}\right]^{2+}$ complex ion in DMF solution at room temperature is represented in Figure 4. The absorption band maxima of the major spectral features are summarized in Table 5. The electronic spectrum of the dimer complex was similar to its monomer analogues. The very similar absorption maxima demonstrate that the dimer complex have similar electronic structure to the monomer complexes.

Using octahedral notation for this complex, the two absorption bands are assigned as ${ }^{4} A_{2 \mathrm{~g}} \rightarrow{ }^{4} T_{2 \mathrm{~g}}$ and ${ }^{4} A_{2 \mathrm{~g}} \rightarrow$ ${ }^{4} T_{1 \mathrm{~g}}(\mathrm{~F}){ }^{8}$ There are overlapping absorption parts in the

Table 5. Electronic transition spectral data of $c i s-\left[\{\mathrm{Cr}([14]-\text { decane })(\mu \text {-cit })\}_{2}\right]^{2+}$ and related $\mathrm{Cr}(\mathrm{III})$ complexes

\begin{tabular}{|c|c|c|}
\hline Complexes & $\lambda, \mathrm{nm}\left(\varepsilon, \mathrm{M}^{-1} \mathrm{~cm}^{-1}\right)$ & refs. \\
\hline trans $-\left[\mathrm{Cr}(\mathrm{en})_{2} \mathrm{Cl}_{2}\right]^{+}$ & 578 (24.5), 453 (23), 396 (34) & $\mathrm{a}$ \\
\hline trans $-\left[\mathrm{Cr}(\text { cyclam }) \mathrm{Cl}_{2}\right]^{3+}$ & 572 (19.9), 407 (35), 365 (41) & a \\
\hline trans- $\left[\mathrm{Cr}(\text { meso-[14]-decane }) \mathrm{Cl}_{2}\right]^{+}$ & $574(25), 440(27), 387(47)^{*}$ & a \\
\hline cis- $\left[\mathrm{Cr}(\mathrm{en})_{2} \mathrm{Cl}_{2}\right]^{+}$ & $528(71), 402(69)$ & a \\
\hline cis- $\left[\mathrm{Cr}(\mathrm{en})_{2}\left(\mathrm{H}_{2} \mathrm{O}\right)_{2}\right]^{3+}$ & 484 (67), 366 (43) & a \\
\hline cis- $\left[\mathrm{Cr}(\mathrm{en})_{2}\left(\mathrm{NH}_{3}\right)_{2}\right]^{3+}$ & $460(66), 351(54)$ & $\mathrm{b}, \mathrm{c}$ \\
\hline cis- $\left[\mathrm{Cr}(\text { cyclam }) \mathrm{Cl}_{2}\right]^{+}$ & $529(111), 404$ (106) & $\mathrm{d}$ \\
\hline cis- $\left[\mathrm{Cr}(\text { cyclam })\left(\mathrm{H}_{2} \mathrm{O}\right)_{2}\right]^{3+}$ & 483 (126), 370 (38) & $b, d$ \\
\hline cis- $\left[\mathrm{Cr}(\text { cyclam })\left(\mathrm{H}_{2} \mathrm{O}\right)\left(\mathrm{NH}_{3}\right)\right]^{3+}$ & 476 (110), $362(87)$ & $\mathrm{b}$ \\
\hline cis- $\left[\mathrm{Cr}(\operatorname{cyclam})\left(\mathrm{NH}_{3}\right)_{2}\right]^{3+}$ & 468 (115), 355 (80) & $\mathrm{b}$ \\
\hline cis- $\left[\mathrm{Cr}([14] \text {-decane })(\mathrm{OH})_{2}\right]^{+}$ & $609(111), 380(73)$ & $\mathrm{e}$ \\
\hline cis-[Cr([14]-decane $\left.)(\mathrm{OH})\left(\mathrm{H}_{2} \mathrm{O}\right)\right]^{2+}$ & $572(130), 407(53)$ & $\mathrm{e}$ \\
\hline cis-[Cr([14]-decane $\left.)\left(\mathrm{H}_{2} \mathrm{O}\right)_{2}\right]^{3+}$ & 529 (169), $388(82)$ & $\mathrm{e}$ \\
\hline cis-[Cr([14]-decane $\left.)(\mathrm{bz})_{2}\right]^{+* *}$ & 548 (223), 394 (131) & $\mathrm{f}$ \\
\hline cis-[Cr([14]-decane $\left.)(\mathrm{cbz})_{2}\right]^{+* *}$ & 547 (221), 394 (127) & $\mathrm{f}$ \\
\hline cis- $\left[\{\mathrm{Cr}([14] \text {-decane })(\mu \text {-cit })\}_{2}\right]^{2+}$ & $532(186), 385(97)^{*}$ & this work \\
\hline
\end{tabular}

a, b, c, d, e, f taken from ref. 32, 25, 33, 34, 21, and 25 (b) respectively. ${ }^{*}$ DMF solution. ${ }^{* *}$ Abbreviations, bz and cbz are benzoate and chlorobenzoate ions 


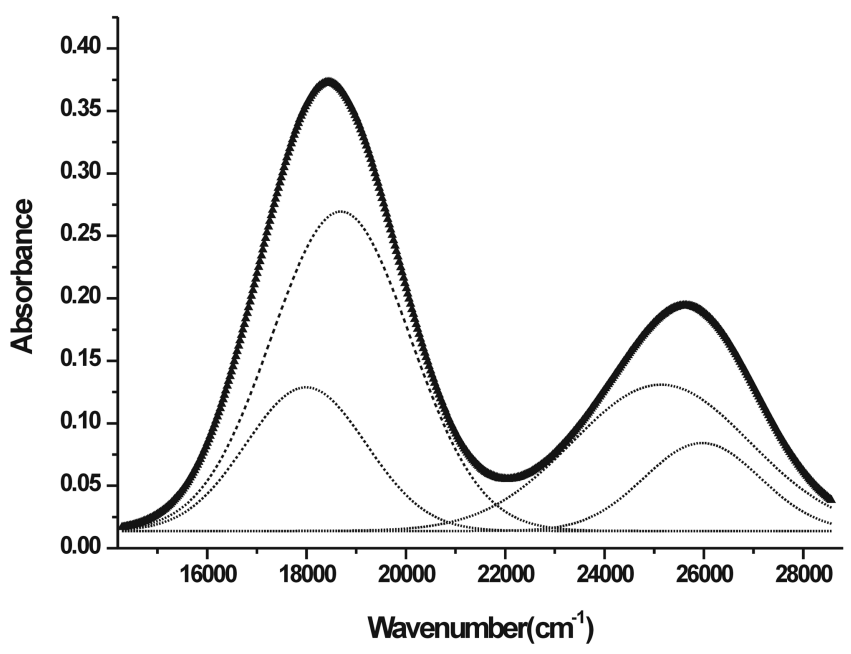

Figure 4. The electronic absorption spectrum of $2.0 \times 10^{-3} \mathrm{M}$ cis$\left[\{\mathrm{Cr}([14]-\text { decane })(\mu \text {-cit })\}_{2}\right]^{2+}$ in DMF solution at $298 \mathrm{~K}$.

spectrum of the title complex including the two distinct bands. Three ligand field bands are expected for a $d^{3}$ ion, ${ }^{4} A_{2 \mathrm{~g}} \rightarrow{ }^{4} T_{2 \mathrm{~g}}$ and ${ }^{4} A_{2 \mathrm{~g}} \rightarrow{ }^{4} T_{1 \mathrm{~g}}(\mathrm{~F})$ and the two electron transition ${ }^{4} A_{2 \mathrm{~g}} \rightarrow{ }^{4} T_{\mathrm{gg}}(\mathrm{P})$ in octahedral and pseudo octahedral symmetry. ${ }^{25}$ The two $d$ - $d$ bands of title complex observed at $\sim 18470, \sim 25650 \mathrm{~cm}^{-1}$ can be related to the spin-allowed transitions, ${ }^{4} A_{2 \mathrm{~g}} \rightarrow{ }^{4} T_{2 \mathrm{~g}}$ and ${ }^{4} A_{2 \mathrm{~g}} \rightarrow{ }^{4} T_{\mathrm{lg}}$, respectively. $^{4}$

In order to obtain some points of reference for the splitting of the two bands, the band profiles were fitted by using four Gaussian curves, as seen in Figure 4. Finally, we performed least-squares fitting procedures, and the dotted lines in Figure 4 are Gaussian bands representing the approximate deconvolution of the spectrum yielded by the calculations. The four peak positions calculated at 17990, 18690, 25140 and $25970 \mathrm{~cm}^{-1}$ can be assigned to the ${ }^{4} \mathrm{E}\left({ }^{4} \mathrm{~T}_{2 \mathrm{~g}}\right.$ in $O_{h}$ symmetry), ${ }^{4} \mathrm{~B}_{2}\left({ }^{4} \mathrm{~T}_{2 \mathrm{~g}}\right),{ }^{4} \mathrm{E}\left({ }^{4} \mathrm{~T}_{1 \mathrm{~g}}\right)$ and ${ }^{4} \mathrm{~A}_{2}\left({ }^{4} \mathrm{~T}_{1 \mathrm{~g}}\right)$, respectively. ${ }^{37,38}$

The electronic spectroscopic data for $\mathrm{Cr}$ (III) monomeric (or dimeric) species have been rationalised taking into account the $10 D q$ value as criterion. ${ }^{35}$ The energy of the first spin allowed $d$-d transition (10 Dq) for cis-[Cr(III)([14]decane $\left.)\left(\mathrm{L}_{\mathrm{a}}\right)\right]^{\mathrm{n}+}$ complexes increases in the sequence

$$
\begin{aligned}
& \text { cis- }\left[\mathrm{Cr}([14] \text {-decane })(\mathrm{OH})_{2}\right]^{+}< \\
& \text {cis- }\left[\mathrm{Cr}([14] \text {-decane })(\mathrm{OH})\left(\mathrm{H}_{2} \mathrm{O}\right)\right]^{2+}< \\
& \text { cis- }\left[\mathrm{Cr}([14] \text {-decane })\left(\mathrm{H}_{2} \mathrm{O}\right)_{2}\right]^{3+}< \\
& \text { cis- }\left[\{\mathrm{Cr}([14] \text {-decane })(\mu \text {-cit })\}_{2}\right]^{2+}
\end{aligned}
$$

The bidentate ligands often act as a bridge to metal ions such as in $\mathrm{Cr}_{2}\left(\mathrm{CH}_{3} \mathrm{COO}\right)_{4} \cdot 2 \mathrm{H}_{2} \mathrm{O}$. Here, the citrate ions serve as a bridging agent between two $\mathrm{Cr}$-macrocyclic complexes. These bridges make cis- $\left[\{\mathrm{Cr}([14] \text {-decane })(\mu \text {-cit })\}_{2}\right]^{2+}$ more stable, resulting the highest $10 \mathrm{Dq}$ value. Crystal field splitting parameters are also attributed to the intra-molecular hydrogen bond in the dimer between the uncoordinated oxygen atom of the carboxylate group and the secondary amine hydrogen of the macrocycle (Fig. 2). The macro- tricycle, which contain two macrocyclic subunits bound $\mathrm{Cr}$ (III) ion, yield supramolecular compound capable of binding inorganic and organic groups. Of course, macrotricyclic compound containing two $\mathrm{Cr}$ (III)-macrocyclic complexes linked by two citrate anions would exhibit moderate flexibility and stability. ${ }^{36}$

General properties. The IR spectrum displayed N-H stretches from 3300 to $3100 \mathrm{~cm}^{-1}$, C-H stretches from 3000 to $2800 \mathrm{~cm}^{-1}$, and a strong ionic $\mathrm{ClO}_{4}^{-}$band at near 1100 $\mathrm{cm}^{-1}$ and $630 \mathrm{~cm}^{-1}$. ${ }^{39}$ The values of molar conductance for cis- $\left[\{\mathrm{Cr}([14] \text {-decane })(\mu \text {-cit })\}_{2}\right]\left(\mathrm{ClO}_{4}\right)_{2}$ measured in DMF or DMSO correspond to a $1: 2$ electrolytes $\left(\lambda_{\mathrm{M}}=168.6\right.$ $\mathrm{ohm}^{-1} \mathrm{~cm}^{2} \mathrm{~mol}^{-1}$ ), indicating that the auxiliary ligands in the $\mathrm{Cr}$ (III) complexes are not dissociated from the complex in these polar solvents. ${ }^{40}$

The spectrum of title complex exhibit characteristic absorption bands for the carbonyls of the citrate carboxylate ligands in the symmetric and asymmetric vibration regions. Specifically, symmetric stretching vibrations, $v_{\mathrm{s}}\left(\mathrm{COO}^{-}\right)$ appear at $1390 \mathrm{~cm}^{-1}$ and asymmetric stretching vibrations, $v_{\text {as }}\left(\mathrm{COO}^{-}\right)$are observed at $1620 \mathrm{~cm}^{-1}$. The title complex gives a typical band of non-bonded and undissociated carboxylic acid group at $1730 \mathrm{~cm}^{-1}$. All of the carbonyl absorption bands are shifted to lower frequencies compared to those of free citric acid, denoting the changes in the vibrational status of that ligand upon complexation to chromium. The differences between the symmetric and antisymmetric stretches, $\Delta v\left\{=v_{\mathrm{as}}\left(\mathrm{COO}^{-}\right)-v_{\mathrm{s}}\left(\mathrm{COO}^{-}\right)\right\}$are on the order of $200 \mathrm{~cm}^{-1}$, indicating that carboxylate groups are either free or coordinated to the metal ion in a monodentate fashion. ${ }^{41}$ This observation is consistent with the observed X-ray crystal structure of the title complex. The aforementioned assignments are in agreement with previous results for citrate complexes of various metals. ${ }^{42}$

In the FAB mass spectrum of title complex there is a peak at $\mathrm{m} / \mathrm{z} 1053$ corresponding to the molecular ion, cis$\left[\{\mathrm{Cr}([14]-\text { decane })(\mu \text {-cit })\}_{2}\right]^{+}$. The molecular ion is undergone fragmentation to give species such as cis-[Cr([14]-

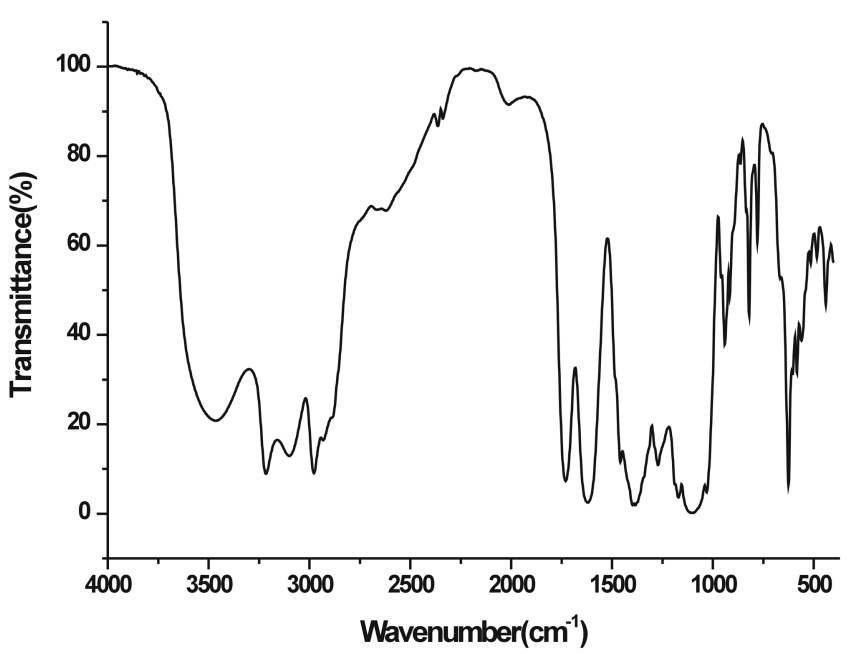

Figure 5. IR spectrum of $c i s-\left[\{\mathrm{Cr}([14]-\text { decane })(\mu \text {-cit })\}_{2}\right]\left(\mathrm{ClO}_{4}\right)_{2}$. $6 \mathrm{H}_{2} \mathrm{O}$. 
decane $\left.)(\mu \text {-cit })_{2}+\mathrm{H}\right]^{+}$, cis- $[\mathrm{Cr}([14] \text {-decane })(\mu \text {-cit })+\mathrm{H}]^{+}$, and cis-[Cr([14]-decane $)+\mathrm{H}]^{+}$at $m / z, 718,526$ and 335, respectively.

\section{References}

1. Strollenwerk, K. G.; Grove, D. B. J. Environ. Analysis 1985, 14, 396.

2. Chisholm, J. J. J. Pediatr. 1986, 73, 1.

3. (a) Wetterhahn, K. E.; Connett, P. H. Struct. Bonding (Berlin) 1983, 54, 93. (b) Mertz, W. J. Nutr. 1993, 123, 626.

4. El-Shahawi, M. S. Spectrochim. Acta 1995, 51A, 161.

5. Toepfer, E. W.; Mertz, W.; Polansky, M. M.; Roginski, E. E.; Wolf, W. R. J. Agric. Fd. Chem. 1977, 25, 162.

6. Green, C. A.; Koline, N.; Legg, J. I.; Willett, R. D. Inorg. Chim. Acta 1990, 176, 82.

7. O'Brien, P.; Ozolins, Z.; Wang, G. Inorg. Chim. Acta 1989, 166, 301.

8. El-Shahawi, M. S. Spectrochim. Acta Part A 1996, 52, 139.

9. El-Shahawi, M. S.; Ghazy, S. E. Trans. Metal Chem. 1992, 17, 541.

10. O'Brien, P.; Wang, G. Polyhedron 1993, 12, 1409

11. (a) Glusker, J. P. Acc. Chem. Res. 1980, 13, 345. (b) Hlaïbi, M.; Chapelle, S.; Benaïssa, M.; Verchère, J. F. Inorg. Chem. 1995, 34, 4434. (c) Zhang, H.; Zhao, H.; Qi, Y.; Hui-Lin, W. Inorg. Chim. Acta 2003, 351, 311.

12. Tsaramyrsi, M.; Kaliva, M.; Salifoglou, A.; Raptopoulou, C. P.; Terzis, A.; Tangoulis, V.; Giapintzakis, J. Inorg. Chem. 2001, 40, 5772.

13. Davis, C. D.; Greger, J. L. Am. J. Clin. Nutr. 1992, 55, 747.

14. Chappuis, P.; Poupon, J.; Arnaud, J. Trace Elements and Free Radicals in Oxidative Diseases; AOCS Press: Champaign, 1994; $\mathrm{p} 46$.

15. Allgood, G. S.; Perry, J. J. J. Bacteriol 1986, 168, 563.

16. Aschner, M. Metals and Oxidative Damage in Neurological Disorders; Connor, J. R., Ed.; Plenum Press: New York, 1997; Chapter 5, pp 77-130.

17. (a) Zhao-Hui, Z.; Hui-Lin, W.; Khi-Rui, T. Polyhedron 1997, 16, 75. (b) Matzapetakis, M.; Karligiano, N.; Bino, A.; Tangoulis, V.; Giapintzakis, J.; Salifoglou, A. Inorg. Chem. 2000, 39, 4044. (c) Dakanali, M.; Kefalas, E.; Raptopoulou, C. P.; Terzis, A.; Salifoglou, A. Inorg. Chem. 2003, 42, 2531. (d) Cawich, C. M.; Lbrahim, A.; Link, K. L.; Patro, M. D.; Mahapatro, S. N.; Lay, P. A.; Levina, A.; Eaton, S. S.; Eaton, G. R. Inorg. Chem. 2003, 42, 6458.

18. Kim, J.; Cho, J.; Lough, A. J. Inorg. Chim. Acta 2001, 317, 252.

19. Perrin, D. D.; Armarego, W. L. F. Purification of Laboratory Chemicals, $3^{\text {rd }}$ Ed.; Pergamon: Oxford, 1988.

20. Curtis, N. F. J. Chem. Soc. 1964, 2644.
21. Eriksen, J.; Mønsted, O. Acta Chem. Scand. 1983, A37, 579.

22. Eriksen, J.; Mønsted, L.; Mønsted, O. Inorg. Chim. Acta 2002, 337, 143.

23. Sheldrick, G. M. Acta Crystallogr. 1990, A46, 467.

24. Sheldrick, G. M. SHELXL-97, Program for the Refinement of Crystal Structures; University of Göttingen: Germany, 1997.

25. (a) Kane-Maguire, N. A. P.; Wallace, K. C.; Miller, D. B. Inorg. Chem. 1985, 24, 597. (b) Byun, J. C.; Kim, G. C.; Han, C. H. Bull. Korean Chem. Soc. 2004, 25, 977.

26. (a) Bang, E.; Mønsted, O. Acta Chemica Scandinavica A 1984, 38, 281. (b) Lessard, R. B.; Heeg, M. J.; Buranda, T.; Perkovic, M. W.; Rudong, Y.; Endicott, J. F. Inorg. Chem. 1992, 31, 3091. (c) Malcoim, A. D. L.; Xianhui, B.; Peter, C. F. Inorg. Chim. Acta 2000, 300, 944.

27. (a) Zhou, Z.; Wan, H.; Hu. S.; Tsai, K. Inorg. Chim. Acta 1995, 237, 193. (b) Tsaramyrsi, M.; Kavousanaki, D.; Raptopoulou, C. P.; Salifoglou, A. Inorg. Chim. Acta 2001, 320, 47. (c) Sylvia, R.; Thomas, W.; Eckhard, B.; Phalguni, C. Inorg. Chim. Acta 2002, 339, 71. (d) Stearns, D. M.; Armstrong, W. H. Inorg. Chem. 1992, $31,5178$.

28. Ceniceros-Gomez, A. E.; Barba-Behrens, N.; Castillo-Blum, S. E. Polyhedron 2000, 19, 1821.

29. Hodgson, D. J.; Pedersen, E.; Toftlund, H.; Weiss, C. Inorg. Chim. Acta 1986, 120, 177.

30. Félix, V.; Santos, T. M.; Madureira, J.; Mirante, F.; Quintal, S.; Goodfellow, B. J.; Santana-Marques, M. G.; Jesus, J. P.; Drew, M. G. B.; Calhorda, M. J. Inorg. Chim. Acta 2003, 356, 335.

31. Glendening, E. D.; Feller, D.; Thompson, M. A. J. Am. Chem. Soc. 1994, 116, 10657.

32. House, D. A.; Hay, R. W.; Ali, M. A. Inorg. Chim. Acta 1983, 72, 239.

33. Wong, C. F. C.; Kirk, A. D. Inorg. Chem. 1978, 17, 1672.

34. Ferguson, J.; Tobe, M. L. Inorg. Chim. Acta 1970, 4, 109.

35. Ceniceros-Gómez, A. E.; Barba-Behrens, N.; Nöth, H.; CastilloBlum, S. E. Polyhedron 2000, 19, 1821.

36. Motekaitis, R. J.; Martell, A. E.; Lecomte, J. P.; Lehn, J. M. Inorg. Chem. 1983, 22, 609.

37. Ueki, S.; Yamauchi, J. Inorg. Chim. Acta 2002, 338, 13.

38. (a) Choi, J. Spectrochim. Acta, Part A 2000, 56, 1653. (b) Choi, J.; Oh, I.; Linder, R.; Schönherr, T. Chem. Physics 2004, 297, 7.

39. Matzapetakis, M.; Karligiano, N.; Tangoulis, V.; Giapintzakis, J.; Salifoglou, A. Inorg. Chem. 2000, 39, 4044.

40. (a) Matzapetakis, M.; Raptopoulou, C. P.; Terzis, A.; Lakatos, A.; Kiss, T.; Salifoglou, A. Inorg. Chem. 1999, 38, 618. (b) Dakanali, M.; Kefalas, E. T.; Raptopoulou, C. P.; Mavromoustakos, T.; Salifoglou, A. Inorg. Chem. 2003, 42, 2531.

41. Nakamoto, K. Infrared and Raman Spectra of Inorganic and Coordination Compounds, Part B; John Wiley \& Sons: New York, 1997.

42. Geary, W. J. Coord. Chem. Rev. 1972, 7, 81. 